\title{
MARKETING ORIENTED ORGANIZATIONAL CULTURE - DOES IT EXIST IN SERBIAN MECHANICAL INDUSTRY?
}

\author{
Ljiljana Pecić, Milivoj Klarin
}

Professional paper

The purpose of this paper is to determine if there is market orientation of organizational culture in Serbian Companies from Mechanical Industry. This research included 21 companies from Serbian metal industry and the questionnaire was used to investigate the level of market orientation through all hierarchical levels. Research results showed that the total level of market orientation of examined companies is unsatisfactory and it can be concluded that the long-term existence of contractual economy in the economy of Serbia leads to the state that its principles still exist in the way of thinking of employees.

Keywords: marketing orientation; organizational culture; TQM

Marketinški orijentirana organizacijska kultura - da li postoji u srpskoj strojarskoj industriji?

Stručni članak

Svrha ovog članka je utvrditi jesu li poduzeća koja posluju u okviru srpske strojarske industrije marketinški orijentirana. Ovo istraživanje je uključilo 21 poduzeće iz Srbije i korišten je upitnik za istraživanje razine marketinške orijentacije u tim poduzećima na svim hijerarhijskim razinama u ovim poduzećima. Rezultati su pokazali da je razina marketinške orijentacije u svim poduzećima na nezadovoljavajućoj razini te da se može zaključiti da principi dogovorne ekonomije, zbog njenog dugog prisustva na ovim područjima i dalje postoje u razmišljanjima svih zaposlenih.

Ključne riječi: marketinška orijentacija; organizaciona kultura; totalno upravljanje kvalitetom (TQM)

\section{Introduction}

Change is a progress from the present state toward a future one [1] or, generally, a response to some significant threat or opportunity arising outside an organization [2]. Changes are everyday facts. We change the way we communicate, the way we do business or work processes almost every day. If an organization wants to survive in the era of market globalization and liberalization, it has to be prepared to cope with rapid changes in business environment. The process of change within any organization is unique and dependable on a specific situation, due to differences in the nature of an organization, the nature of business, the work culture and values, management and leadership style [3] and national culture and tradition. These changes have compelled organizations to consider restructuring and reengineering in order to achieve business excellence.

It is well known that business excellence in companies is realized through implementation of the concept of total quality management (TQM). TQM is seen as a description of the culture, attitude and organization of a company that aims to provide products and services to customers that meet their needs. The culture requires quality in all aspects of organizational operations, with things being done the right way instantaneously, with defects and waste being simultaneously eradicated from its operations [4]. TQM is the culture in an organization committed to total customer satisfaction through continuous improvement. That is why resources in such cultures are totally utilized $[5,6]$. Benefit comes in all segments of business: fewer defects, reduced rework and lead times, lower inventory levels, cost reduction, and higher level of customer satisfaction $[7,8]$. The overall marketing effectiveness is achieved as a mixture of hierarchy, and market and adhocracy elements, which is strongly customer oriented with a high degree of inter-functional coordination.

TQM might have a dramatic influence on the organizational culture $[9,10]$. It is a managerial approach where the application of team work and partnership relations with both consumers and suppliers are basic tools for culture transformation and its implementation implies serious cultural changes within a company [11]. Till the end of 1993, only 20 to 35 per cent of companies which have implemented it, had improvements in quality, productivity and competitiveness [12, 13, 14]. Chances for success of TQM programs are better if the overwhelming organizational culture is compatible with TQM basic principles and values [15]. This means that the success of TQM, as an organizational change, will depend on organizational culture to a great extent [16] and that before implementing TQM organizational culture should be examined by organizational development practitioners [17].

Implementing TQM means changes, and for all changes organizational culture is a key. Altering the way people perceive changes and react on them plays an important role in such efforts $[18,19,20]$.

Slater [21] expressed this notion explicitly when stating "A market orientation is the aspect of business culture that motivates employees throughout the organization to place the highest priority on the profitable creation and maintenance of superior customer value. As such, it establishes norms for behaviour regarding the organization-wide development of and responsiveness to information about customers and competitors, both current and potential." Slater [21] distinguishes between the traditional and new approach to market orientation. "Market-oriented businesses have traditionally focused on understanding the expressed needs of the customers in their served markets and on developing products and services that satisfy those needs [21]." In this way, market orientation is focusing on current products and services, 
incremental rather than breakthrough learning and the short term. Slater [21] continues by stating that the "Second generation market-oriented businesses are committed to understanding both the expressed and unexpressed needs of their customers, and the capabilities and plans of their competitors through the processes of acquiring and evaluating market information in a systematic and anticipatory manner." In meta-analysis of the many articles investigating the relationship between market orientation and business performance, Rodriquez Cano, Carillat and Jaramillo [22] concluded that this relationship is positive and consistent worldwide.

A lot of companies in the world did not succeed on the road to achieve business excellence and TQM. Now, if we assume that company's culture influences everything it does, it is clear that if you want to achieve TQM business excellence in the era of globalization, you have to be marketing oriented. Companies all around the world in their visions have defined that they want this, but on the field everything is different. Research results from all over the world show us that even in developed economies such risky ventures have a high percentage of failure.

Problems in developing world economies have mainly four-dimensional character [23, 24]:

- lack of quality marketing practices,

- lack of adequate technological equipment,

- lack of adequate financial means, and

- lack of satisfactory management behaviour.

For economies in transition, there is another important issue - the noted presence of political and economic instability [23, 24]. Final goal for all changes in companies all round the world is achieving TQM philosophy. As we know, company can follow orientation that matches one of three categories: product-oriented, sales-oriented or market oriented. For business on global market, market orientation is seen as a must category; company must meet customer needs and demands and be able to predict them. To help companies to develop their forces, science must insist on methodological solutions whose base will be the essence of TQM philosophy - the participation of total workforce and orientation to customer satisfaction, i.e. existence of 'marketing oriented organizational culture'. So, market orientation is necessary for TQM implementation.

The following paragraphs are dealing with evaluating the state of marketing orientation of organizational culture in companies within Serbian mechanical industry.: 20 companies are nowadays entities part of "IHP Prva Petoletka" holding company whereas in the recent past they used to be a part of the giant "IHP Prva Petoletka" in Trstenik (PPT - the field of hydraulics and pneumatics, which gives to almost all of them the prefix PPT) and the company number 21 is also the former giant "IMK - 14 . Octobar" (building machinery production). Eighteen companies are currently undergoing the process of restructuring.

\section{Research}

\subsection{The description of companies-objects of research}

Industry of hydraulics and pneumatics "Prva petoletka Trstenik" (PPT) and Corporation "IMK - 14.
Oktobar Kruševac" are former giants, with headquarters settled in the middle of Serbia. The "IMK - 14. Oktobar" company was founded in 1923, as a limited company whose $90 \%$ of shares were possessed by industrialists from Vienna and Budapest. This company originally dealing with the repair of wagons, had the professional staff consisting of engineers from Vienna and Budapest. This trend lasted till the 1970's when, with the help of local skilled staff, the company started the production of excavators, crawler tractors and rollers. During the period $1968 \div 1973$, it produced 25 new types of machinery using its own design and technology. In the years to come, much was done to expand the production capacity either by its own development capacity, or with the help of licensed cooperation with ZF-player from Germany. Thus, the company became a recognized producer of building and transport machinery and its market was Yugoslavian, Eastern market and Asian and African market.

PPT was settled during 1949 and next 40 years were the years of intensive work and growth. The end of 1989 was greeted with 15000 workers and sales realization more than $\$ 400$ million. A lot about the history of PPT and occasions during its 65 years long history has been said in previously published papers $[23,24]$. Before 1990 all companies in the system were established and some companies were established as production companies and some were established to support the system. No company had direct contact with the market, according to principles of contractual economy.

For this research it is important to say that PPT became a holding company during 1991. That holding company had 23 companies directed towards one another and that type of organization was settled because the holding is much more flexible than the corporation.

After years of stagnation (1990 till 1994), during 1994 till 1999 when PPT started to open itself to global market, some progress was made. All companies got some freedom in business and Government pressure slowed down. Project of ISO 9001 implementation was launched, market forces are created and results reached in that period are presented in Tab. 1, Fig. 1, Fig. 2 and Fig. 3 .

Table 1 Business results obtained from 1994 till 1998

\begin{tabular}{|c|c|c|c|c|c|c|c|}
\hline Indicator & Sales & Export & A & B & C & D & $\mathrm{E}$ \\
\hline Year & $(\mathrm{mil} \$)$ & $(\mathrm{mil} \$)$ & $\pi$ & D & 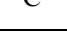 & & \\
\hline 1994 & 32 & 2,5 & 24 & 230 & 9,5 & 62 & 2,7 \\
\hline 1995 & 37 & 4 & 30 & 270 & 11 & 83 & 2,5 \\
\hline 1996 & 45 & 6 & 37 & 320 & 13,5 & 110 & 2,3 \\
\hline 1997 & 58 & 8,5 & 49 & 380 & 16,5 & 150 & 2,1 \\
\hline 1998 & 76 & 11,5 & 62 & 460 & 20 & 196 & 1,9 \\
\hline \multicolumn{8}{|c|}{$\begin{array}{l}\text { A - Capacity utilization through time shifts; B - Physical volume of } \\
\text { production ( thousand conditional products); C - AWP- average } \\
\text { working productivity (conditional units per worker); D - Average Paid } \\
\text { Salary (US\$); E - Salary delay (months). }\end{array}$} \\
\hline
\end{tabular}

The period from 1999 till 2010 was marked by frequent changes in top management whose members brought different ideas about what should be done with PPT. That is why a lot of organizational changes have been made. Some companies disappeared, some went legally from the system, one part became public company, some were integrated. At the middle of 2010, PPT was a system whose organization was very hard to explain. Tab. 
2 shows the status of companies during 2010, at the time when this research begun.

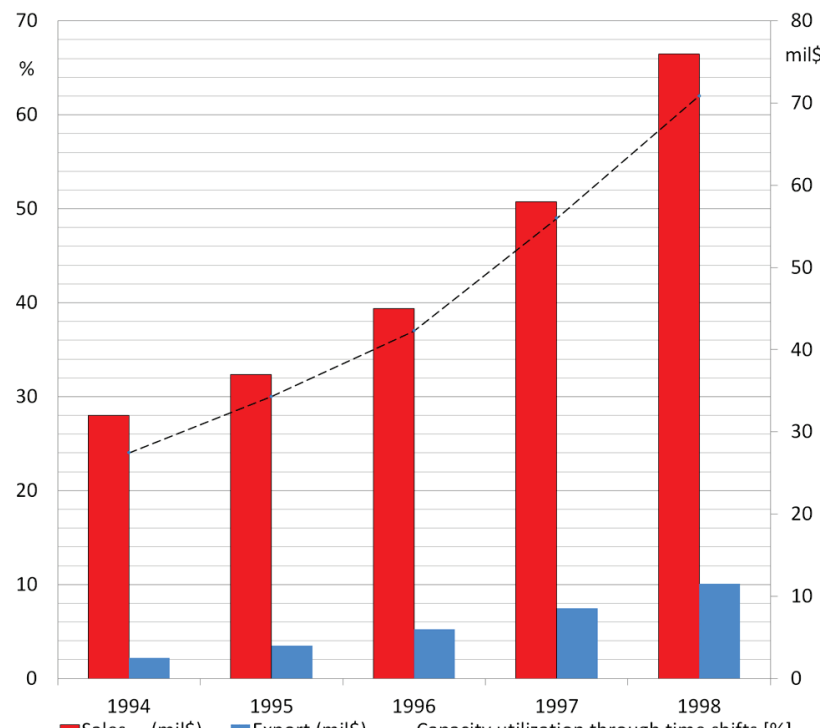

ESales (mil\$) Export (mil\$) $\rightarrow-$-Capacity utilization through time shifts [\%]

Figure 1 Moves in sales, export and capacity utilization from 1994 till 1998

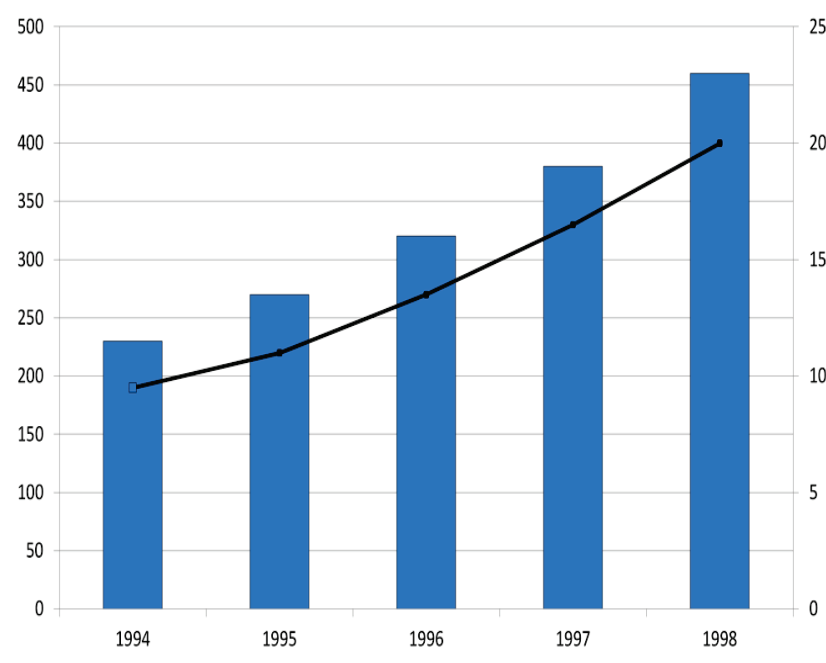

EB- Physical volume of production ( thousand conditional products) -C-AWP(conditional units per worker)

Figure 2 Moves in physical volume of production and AWP from 1994 till 1998

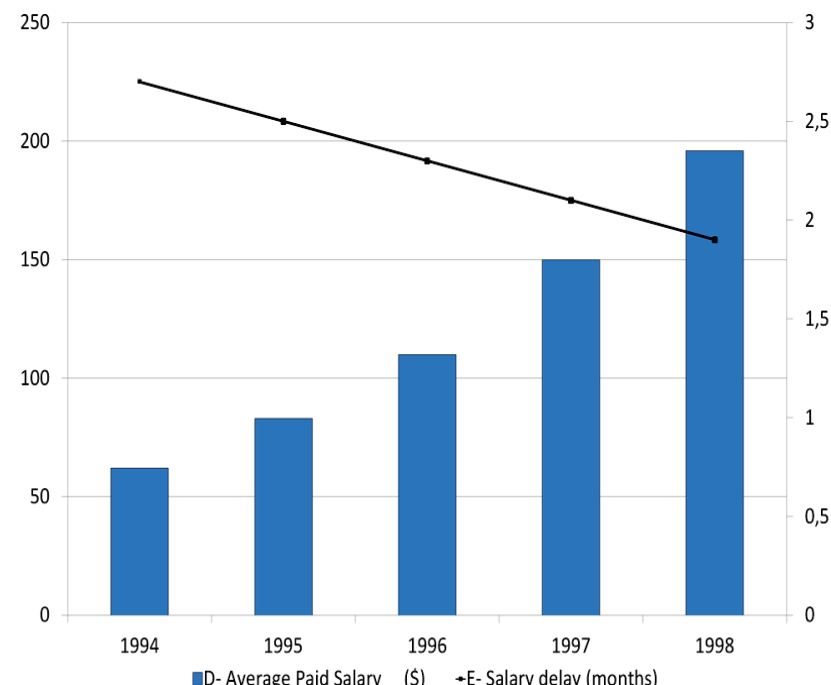

Figure 3 Moves in average paid sales and salary delay from 1994 till 1998
The Serbian Government, aware of importance of those companies, spent 1740537221,75 euros as subsidies to companies members of two first groups of companies during period from 2003 till July 2011. At the middle of 2010, the Serbian Government lunched the project of their recovery.

This paper is going to present detailed results of investigating the level of market-orientation in all companies, earlier members of PPT and company "IMK14. Oktobar" and the results obtained here are the start point for defining the methodology for their recovery.

Table 2 Organizational structure and status of companies involved in PPT at the end of 2010

\begin{tabular}{|c|c|c|}
\hline \multirow{12}{*}{$\begin{array}{l}\text { Holding } \\
\text { Company }\end{array}$} & PPT - Holding preduzeće & \\
\hline & PPT - Ishrana & \\
\hline & PPT - Obezbeđenje & \\
\hline & PPT- Remont i energetika & \\
\hline & PPT -Cilindri & \\
\hline & PPT - Hidraulika & \\
\hline & PPT - Industrijska pneumatika & \\
\hline & PPT- Delovi Novi Pazar & \\
\hline & Petoletka promet & \\
\hline & PPT - Transport & $\begin{array}{l}\text { privatization in } \\
\text { progress }\end{array}$ \\
\hline & PPT - NIC & $\begin{array}{l}\text { company in the } \\
\text { quenching process }\end{array}$ \\
\hline & PPT - Inženjering & $\begin{array}{l}\text { privatized at the end } \\
\text { of } 2010\end{array}$ \\
\hline \multirow{7}{*}{$\begin{array}{c}\text { Legally } \\
\text { Independent }\end{array}$} & PPT - Kočna tehnika & \\
\hline & PPT - Servoupravljači & \\
\hline & PPT - Armature & \\
\hline & PPT - FUD Brus & \\
\hline & PPT - TMO & \\
\hline & PPT - Zaptivke & \\
\hline & PPT - Namenska & $\begin{array}{l}\text { under special } \\
\text { treatment of Ministry } \\
\text { of Defence }\end{array}$ \\
\hline \multirow{3}{*}{$\begin{array}{l}\text { Something } \\
\text { else }\end{array}$} & PPT - Delovi Belo Polje & $\begin{array}{l}\text { privatized, not } \\
\text { existing any more }\end{array}$ \\
\hline & PPT - Zglobni ležajevi & $\begin{array}{l}\text { under special } \\
\text { treatment, Kosovo }\end{array}$ \\
\hline & Energetika & public company \\
\hline
\end{tabular}

\subsection{Research implementation on chosen companies}

For identifying the present level of the organizational culture in terms of marketing orientation in 21 companies involved in mechanical industry an appropriate questionnaire, presented in Tab. 3 [23, 24] based on MARK - PLAN questionnaire [25], was used. Every question had three possible answers and behind each answer was one of possible orientations: on product, on sales or on market. All researches in Serbia previously done on this subject were based on investigating opinions of top-management. According to the fact that all deep changes, especially those which have ambition to achieve TQM, this study was done among all levels in companies. Study involved 3095 workers (from 5993) and it was conducted during four months, starting at the beginning of December 2010. Detailed procedure of conducting study was explained in two previously published papers and part of results are presented there [23, 24].

Scale used for evaluating results is shown in Tab. 4 . 


\begin{tabular}{|c|c|c|c|}
\hline $\begin{array}{c}\text { Company orientation/ } \\
\text { Questions }\end{array}$ & $\begin{array}{l}\text { Production } \\
\text { orientation }\end{array}$ & $\begin{array}{c}\text { Sales } \\
\text { orientation }\end{array}$ & $\begin{array}{c}\text { Market } \\
\text { orientation }\end{array}$ \\
\hline $\begin{array}{l}\text { 1) Which existing problem should } \\
\text { be given the highest priority? } \\
\text { (problem identification) }\end{array}$ & Production & Sales & Meeting consumer needs \\
\hline $\begin{array}{l}\text { 2) It would be possible to revive } \\
\text { the company if... (vision of fate) }\end{array}$ & The State provides adequate support & $\begin{array}{c}\text { Market behaviour becomes more } \\
\text { regular }\end{array}$ & $\begin{array}{c}\text { Customer needs are met in a quality } \\
\text { way }\end{array}$ \\
\hline $\begin{array}{l}\text { 3) Apart from the CEO, the } \\
\text { second most important function in } \\
\text { the company is... (identification of } \\
\text { the most important role in a } \\
\text { company) }\end{array}$ & Technical Manager & Commercial Manager & Marketing Manager \\
\hline $\begin{array}{l}\text { 4) What should special attention } \\
\text { be paid to? (How do you see } \\
\text { yourself in the future) }\end{array}$ & Production Performance & Sales Performance & Meeting customers' requirements \\
\hline $\begin{array}{l}\text { 5) The basic goal of the company } \\
\text { for all employees is gaining... }\end{array}$ & $\begin{array}{l}\text { Quality performance of assigned } \\
\text { tasks }\end{array}$ & Profitability & Long-term perspective \\
\hline $\begin{array}{l}\text { 6) From the external point of } \\
\text { view, it is very important for the } \\
\text { company to develop... }\end{array}$ & $\begin{array}{c}\text { A good relationship with respective } \\
\text { power centres } \\
\text { (characteristics of a consensus } \\
\text { economics) }\end{array}$ & $\begin{array}{l}\text { A good relationship with business } \\
\text { partners } \\
\text { (lower supply, higher sales) }\end{array}$ & Quality image in the market \\
\hline $\begin{array}{l}\text { 7) From the marketing point of } \\
\text { view, it is very important for the } \\
\text { company to do... }\end{array}$ & $\begin{array}{l}\text { Active public appearance and } \\
\text { promotion }\end{array}$ & $\begin{array}{l}\text { Promotion in the market and } \\
\text { attraction of users' attention }\end{array}$ & Communication with target groups \\
\hline $\begin{array}{l}\text { 8) The company communicates } \\
\text { with the external public... }\end{array}$ & Through formal notices & By providing information to media & $\begin{array}{l}\text { By using different means intended } \\
\text { to target groups }\end{array}$ \\
\hline $\begin{array}{l}\text { 9) From a managerial point of } \\
\text { view, who makes internal public? }\end{array}$ & The most influential human factors & $\begin{array}{l}\text { Authoritative representatives of } \\
\text { interested groups }\end{array}$ & All employees \\
\hline $\begin{array}{l}\text { 10) Management communicates } \\
\text { with the internal public through... }\end{array}$ & $\begin{array}{c}\text { Formal notices or posting notices on } \\
\text { bulletin boards }\end{array}$ & The information service & $\begin{array}{l}\text { Direct contacts related to specific } \\
\text { issues with interested groups }\end{array}$ \\
\hline $\begin{array}{l}\text { 11) Top management of the } \\
\text { company consists of... }\end{array}$ & $\begin{array}{l}\text { the members representing current } \\
\text { centres of power }\end{array}$ & experts in specific professional areas & experts in corporate management \\
\hline $\begin{array}{l}\text { 12) The primary factor for the } \\
\text { successful operation is ... (type of } \\
\text { exchange) }\end{array}$ & $\begin{array}{l}\text { Production of quality products and } \\
\text { goods }\end{array}$ & $\begin{array}{l}\text { As cheaply buy and produce, and as } \\
\text { dearly sell }\end{array}$ & Quality to meet customer needs \\
\hline $\begin{array}{l}\text { 13) The following is a sign of } \\
\text { management goodwill... }\end{array}$ & $\begin{array}{c}\text { Highlighting individual } \\
\text { contributions generated from } \\
\text { operations }\end{array}$ & $\begin{array}{l}\text { Periodical awards and } \\
\text { commendations }\end{array}$ & Adherence to company's mission \\
\hline $\begin{array}{l}\text { 14) Achieved success in business is } \\
\text { expressed through... }\end{array}$ & $\begin{array}{c}\text { The level of achieved production } \\
\text { volume }\end{array}$ & $\begin{array}{l}\text { The range of achieved market } \\
\text { presence }\end{array}$ & The level of gained market position \\
\hline $\begin{array}{l}\text { 15) The company would do } \\
\text { business more successfully if there } \\
\text { is ... (vision of solution) }\end{array}$ & Better production equipment & Satisfactory current assets & Higher quality of human resources \\
\hline
\end{tabular}

Table 4 Scale for evaluating results

\begin{tabular}{|c|c|}
\hline Level of Market Orientation & Points Scale \\
\hline advanced & $121 \div 150$ points \\
\hline barely satisfactory & $91 \div 120$ points \\
\hline conservative & $61 \div 90$ points \\
\hline bad & $31 \div 60$ points \\
\hline hopeless & $0 \div 30$ points \\
\hline
\end{tabular}

\section{Results presentation and analysis}

As previously mentioned, this study involved 21 companies from Serbia and Fig. 4 gives the structure of: number of workers and number of respondents.

Results of the survey shows that all companies involved in research are conservative systems and that their level of market orientation is not on necessary level. The data about average number of achieved points per questions and per company and the summary and mean values per each company are shown in Tab. 5 .

The average score per question for companies involved in PPT system is 4,887 and the average score per questionnaire is 73,283 . Results are distributed around mean value $\pm 10 \%$. Uniformity of responses clearly indicates that norms, values and assumptions of employees are deeply established among employees, so we can conclude that there is a strong culture in those companies and in all PPT system.
The results are given per all companies, per Level of education (LE) and Years of Working Experience (YWE) for companies involved in ex PPT and per all questions. Graphic presentation per all criteria is given in Fig. 6.

If we look at results shown in Tab. 6 , we can notice that the best average score was achieved by the young workers (apprentices), with working experience less or equal to 1 year and that the oldest workers have the worst score.

Young workers have higher interest for market orientation than colleagues with higher number of years of working experience and that can be explained by their previous education and time spent in waiting for job. On the other hand, older workers who are at the end of working life are under the influence of long term contractual economy.

Now, if we look at average number of points per all questions we can see that question No. 14 has the lowest average scores of all questions and per all criteria (company, LE, YWE). It can be concluded that in all companies and per all levels of working experience and per all levels of education the employees think that the production volume is something that is crucial for business. They do not understand that production is good but only for known customer. 


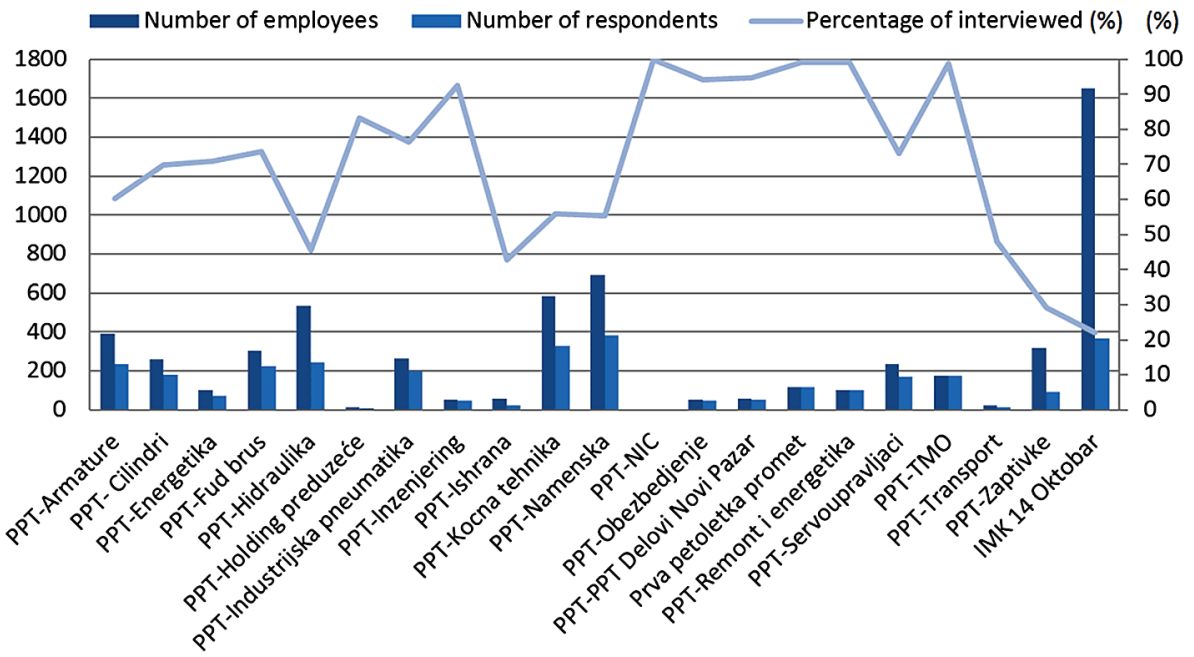

Figure 4 Number of employees and number of respondents per each company

Table 5 Results obtained per companies

\begin{tabular}{|c|c|c|c|c|c|c|c|c|c|c|c|c|c|c|c|c|c|}
\hline & \multicolumn{15}{|c|}{ Questions } & & \\
\hline Name of the Company & 1 & 2 & 3 & 4 & 5 & 6 & 7 & 8 & 9 & 10 & 11 & 12 & 13 & 14 & 15 & SUM & Man \\
\hline PPT-Armature & 4,94 & 4,24 & 4,75 & 4,07 & 4,92 & 6,78 & 5,70 & 5,93 & 5,33 & 3,88 & 3,98 & 4,00 & 5,19 & 2,03 & 4,51 & 71,25 & 4,75 \\
\hline PPT- & 81 & 69 & 33 &, 11 & 6,00 & 5,08 & 6,22 & 4,42 & 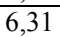 & 2,94 & 6,08 & 5,72 & 6,00 & 3,81 & 5,14 & 0,7 & 5,24 \\
\hline $\begin{array}{l}\text { PPT-E } \\
\end{array}$ & 29 & 49 & 63 & 1,99 & 5 & 7,74 & 5,07 & 4,86 & 07 & 5,27 & 2,95 & 3,70 & 3,84 & 0,55 & 4,66 & & 4,05 \\
\hline $\begin{array}{c}\text { PPT-I } \\
\end{array}$ & 27 & 07 & 5,20 & 4,53 & 6,6 & 5,33 & 6,73 & 3,20 & 6,27 & 3,73 & 4,53 & 6,13 & 6,33 & 3,47 & 4,00 & 7,40 & 5,16 \\
\hline PPT- & & 5,20 & 71 & 4,92 & $\left.\right|_{1}$ & 60 & 4,34 & $71+3+3$ & 4,90 & 3,20 & 5,12 & 4,49 & 5,82 & 3,18 & 3,09 & & 4,56 \\
\hline$\overline{\mathrm{PP}}$ & & & 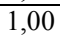 & & & & & & & 3 , & 2,50 & 2,5 & 8,50 & 4, & 3,0 & & 4,07 \\
\hline$\overline{\mathrm{PPT}}$ & 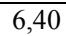 & & 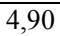 & $7,7($ & 4, & 7. & 5,7 & 5.6 & 6 & 2 , & 6,6 & 4,7 & 7,0 & 2,1 & 2,8 & & 5,08 \\
\hline PPT & 51 & 3,16 & 5,51 & 0 & 5 , &, 12 & 5, & 5,6 & $7,4$. & 1,3 & 6,3. & 4,08 & 7,76 & 2,55 & 3,06 & 18 & 4,95 \\
\hline PPT & 83 & 54 & 5,21 & 3,75 & 6,88 & 3,13 & 7,71 & 8,54 & 4,79 & 3,96 & 2,08 & 4,79 & 6,67 & 2,92 & 5,00 & 4,79 & 4,99 \\
\hline $\begin{array}{l}\text { PPT- } \\
\text { - }\end{array}$ & 94 & 4,42 & 5,06 & 4,91 & 6,04 & 4,57 & 5,47 & 4,73 & 5,24 & 3,37 & 5,21 & 5,37 & 5,99 & 2,94 & 4,39 & 2,65 & 4,84 \\
\hline PPT & 45 & 1,41 & 4,48 & 3,63 & 4 & 6,84 & 5,27 & 5,04 & 5,84 & 3,93 & 3,77 & 3,75 & 5,16 & 1,97 & 4,26 & 7,78 & 4,52 \\
\hline $\begin{array}{l}\mathrm{PPT} \\
\end{array}$ & 25 & 2,50 & 6,25 & 2,50 & & 25 & 3,75 & $2=$ & 25 & 1,25 & 2,50 & 3,75 & 5,00 & 2,50 & 1,25 & 75 & 3,58 \\
\hline & & & & & & & 7, & & & 3,11 & 4,0 & 5,6 & 6,7 & 1,84 & 3, & & 5,38 \\
\hline PPT & 60 & 40 & 5,19 & 5,09 & 5,47 & 47 & 5,19 & 3,6 & 5.19 & 3,1 & 5,75 & 6.1 & 5,28 & 4,34 & 4,62 & 3,77 & 4,92 \\
\hline Prys & 38 & 19 & 5,89 & 3,98 & 6,78 & 53 & 6,06 & 2,7 & 5,55 & 3,3 & 4,1 & 62 & 5,85 & 3,22 & 3,86 & 2,46 & 4,83 \\
\hline PPT & 7,20 & 3,80 & 6,75 & 6,65 & 4,60 & 6,40 & 6,15 & 5,60 & 6,80 & 3,10 & 5,75 & 6,05 & 6,50 & 2,70 & 3,65 & 1,70 & 5,45 \\
\hline PPT- & 92 & 3,81 & 4,33 & 4,16 & 6,54 & 7,38 & 6,48 & 6,95 & 6,54 & 2,97 & 6,25 & 5,49 & 6,98 & 4,30 & 2,03 & 81,13 & 5,41 \\
\hline PPT- & 5,48 & 4,12 & 4,49 & 3,78 & 5,31 & 5,80 & 5,71 & 3,92 & 6,51 & 2,61 & 6,02 & 3,89 & 6,28 & 3,27 & 3,52 & 0,71 & 4,71 \\
\hline PPT-1 & 8,33 & 6,67 & 7,92 & 7,50 & 5,8 & 5,42 & 5,00 & 3,33 & 4,58 & 2,92 & 4,17 & 5,00 & 6,67 & 1,25 & 3,75 & 78,33 & 5,22 \\
\hline & 83 & 4,25 & 5,54 & 4,89 & & 6,77 & 6,67 & 5,7 & 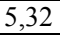 & 4,46 & 5,75 & 5,22 & 7,47 & 2,31 & 2,58 & 3,39 & 5,23 \\
\hline 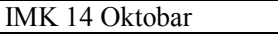 & r & 4,43 & 4,49 & 3,70 & 4,99 & 6,87 & 5,26 & 5,12 & 5,82 & 4,00 & 3,77 & 3,85 & 5,18 & 2,32 & 4,23 & 68,57 & 4,57 \\
\hline
\end{tabular}

Table 6 Results obtained per Years of Working Experience (YWE) in PPT

\begin{tabular}{|c|c|c|c|c|c|c|c|c|c|c|c|c|c|c|c|c|c|}
\hline & \multicolumn{10}{|c|}{ Question } & \multicolumn{10}{|c|}{ (12 } & & \\
\hline WE & 1 & 2 & 3 & 4 & 5 & 6 & 7 & 8 & 9 & 10 & 11 & 12 & 13 & 14 & 15 & SUM & Mean \\
\hline $0 \div 1$ & 5,38 & 4,81 & 6,35 & 5,77 & 3,85 & 6,15 & 6,15 & 5,38 & 7,12 & 3,27 & 4,42 & 5,00 & 5,77 & 4,62 & 2,69 & 76,73 & 5,12 \\
\hline $2 \div 5$ & 4,65 & 5,00 & 3,42 & 4,29 & 4,86 & 6,60 & 5,21 & 4,93 & 5,68 & 3,25 & 4,72 & 4,60 & 5,94 & 2,50 & 4,74 & 70,40 & 4,69 \\
\hline $6 \div 10$ & 5,70 & 4,57 & 4,87 & 4,01 & 5,63 & 5,85 & 5,56 & 4,80 & 5,76 & 3,45 & 4,87 & 4,46 & 5,74 & 2,17 & 3,63 & 71,08 & 4,74 \\
\hline $11 \div 25$ & 5,54 & 4,45 & 5,17 & 4,81 & 5,53 & 6,18 & 5,86 & 4,96 & 6,06 & 3,33 & 5,26 & 4,94 & 6,16 & 3,08 & 3,81 & 75,13 & 5,01 \\
\hline $26 \div 35$ & 5,32 & 4,34 & 4,93 & 4,15 & 5,61 & 5,99 & 5,71 & 4,60 & 5,80 & 3,46 & 4,83 & 5,14 & 5,98 & 2,68 & 3,77 & 72,30 & 4,82 \\
\hline $36 \div 50$ & 7,61 & 1,96 & 6,09 & 3,04 & 7,17 & 4,57 & 5,65 & 3,26 & 4,57 & 2,61 & 5,22 & 4,35 & 5,87 & 1,96 & 1,52 & 65,43 & 4,36 \\
\hline Managers & 6,30 & 2,78 & 3,89 & 5,00 & 5,00 & 6,11 & 7,41 & 5,56 & 4,63 & 3,89 & 3,89 & 5,74 & 5,74 & 1,67 & 3,52 & 71,11 & 4,74 \\
\hline
\end{tabular}

If we look at Tab. 7, it can be concluded that the best score have employees with third level of education. It is especially disturbing that managers, the people who have to be the most aware of the situation, have score 71,11 . Taking into account that managers should lead changes, we can conclude that these top managers are not able to do that, because their values, beliefs and principles are not market oriented and they do not believe in market principles. This situation can be explained if we know previous history - top managers were promoted under the political influence for the last 15 years. It is a striking fact that the lowest number of points has PPT-NIC (scientific centre) and its director (only respondent) with $9^{\text {th }}$ level of education. They should promote innovativeness in all segments of work, but the fact is that they do not have the necessary market orientation.

From equalization of points per all PPT companies, LE and YWE, it can be concluded that there is no subculture in PPT. In Fig. 5 (spider web graph) the zone of conservative culture $(60 \div 90$ points) is shaded and it can be seen that there is no force for necessary changes.

Involvement of "Energetics" and "IMK-14. Octobar" in research served to confirm one more attitude - that in Serbian Mechanical industry generally does not exist market orientation and that organizational culture is strong and under the deep influence of contractual economy. We can see that during 20 years (from 1990 till 
2010), orientation is changed from product to sales, but market orientation seems still so far.

If there is so considerable uniformity of obtained results among all categories among workers in PPT system like in this case, the ability for change is so small. The potential for changes should be found among young workers, employees with lower level of education, through education and involvement of new topmanagement, but chosen without political influence.

\section{Conclusion}

The research whose results are presented in this paper was conducted for practical reasons, i.e. because of the need to comprehend the existing level of organizational culture of the metal industry in Serbia in order to define further steps in the process of restructuring these companies and involving them in market-oriented business. The obtained results showed us that the level of market orientation of the whole sample is low and that the level of market orientation per all chosen variables (company, years of working experience, level of education) is low.

These results indicate that organizational culture is strong, but it is not in compliance with the environmental tasks, visions of the companies and TQM principles. A deeper analysis shows that due to the long-lasting presence of consensus in economics in Serbia, its principles are still present in thoughts and minds of most employees. Conducted study also showed that there is no subculture in companies, so there is no force in those companies which will be able to conduct so necessary changes without good education. Especially worrisome is the fact that top-management, who should lead changes, has an opinion not in line with market orientation.

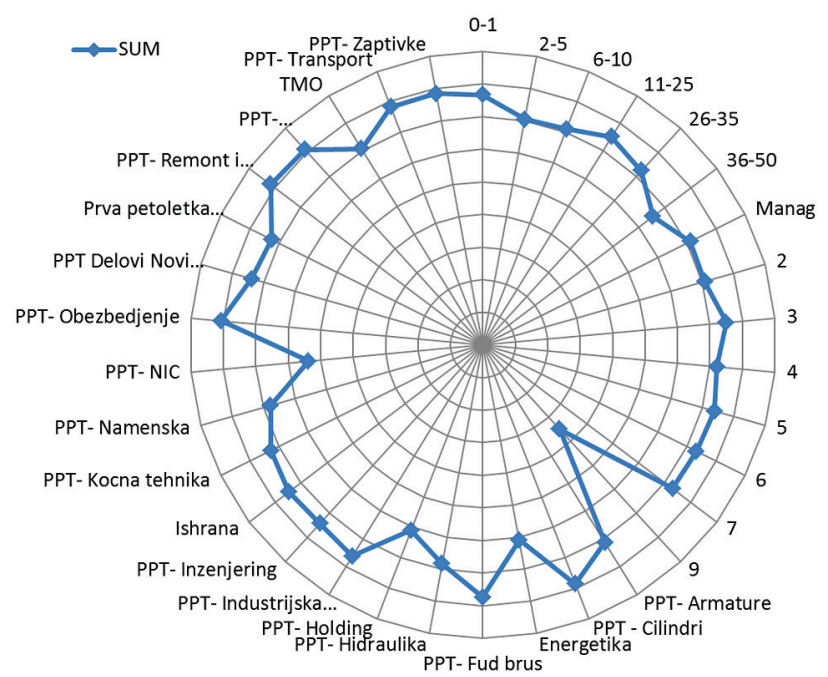

Figure 5 Spider web presentation of points per each criteria in PPT

Table 7 Results obtained per Level of Education (LE) in PPT

\begin{tabular}{|c|c|c|c|c|c|c|c|c|c|c|c|c|c|c|c|c|c|}
\hline LE & Q.1 & Q.2 & Q.3 & Q.4 & Q.5 & Q.6 & Q.7 & Q.8 & Q.9 & Q.10 & Q.11 & Q.12 & Q.13 & Q.14 & Q.15 & SUM & $\begin{array}{c}\text { Mean } \\
\text { Value }\end{array}$ \\
\hline 2 & 5,25 & 5,41 & 3,61 & 4,51 & 5,74 & 6,72 & 4,43 & 5,00 & 6,07 & 3,11 & 4,18 & 4,51 & 5,74 & 1,80 & 4,75 & 70,82 & 4,72 \\
\hline 3 & 5,57 & 4,58 & 5,29 & 4,88 & 5,44 & 5,86 & 5,96 & 4,74 & 5,61 & 3,00 & 5,20 & 5,70 & 6,46 & 3,00 & 3,75 & 75,03 & 5,00 \\
\hline 4 & 5,40 & 4,35 & 4,77 & 4,14 & 5,58 & 6,23 & 5,76 & 4,62 & 5,92 & 3,49 & 4,91 & 4,67 & 5,86 & 2,65 & 3,84 & 72,21 & 4,81 \\
\hline 5 & 5,36 & 4,87 & 5,49 & 4,24 & 6,18 & 6,68 & 5,39 & 5,86 & 6,22 & 2,70 & 5,33 & 4,08 & 5,92 & 2,43 & 3,26 & 74,01 & 4,93 \\
\hline 6 & 5,34 & 4,24 & 5,01 & 4,34 & 5,70 & 5,72 & 5,75 & 4,83 & 5,96 & 3,93 & 4,80 & 4,70 & 6,10 & 3,23 & 3,59 & 73,24 & 4,88 \\
\hline 7 & 5,11 & 4,18 & 4,64 & 4,89 & 4,60 & 6,16 & 5,34 & 5,04 & 6,29 & 3,65 & 5,23 & 5,00 & 5,84 & 2,74 & 4,26 & 72,97 & 4,86 \\
\hline 9 & 5,00 & 0,00 & 5,00 & 0,00 & 0,00 & 5,00 & 5,00 & 0,00 & 5,00 & 0,00 & 0,00 & 5,00 & 5,00 & 0,00 & 0,00 & 35,00 & 2,33 \\
\hline
\end{tabular}

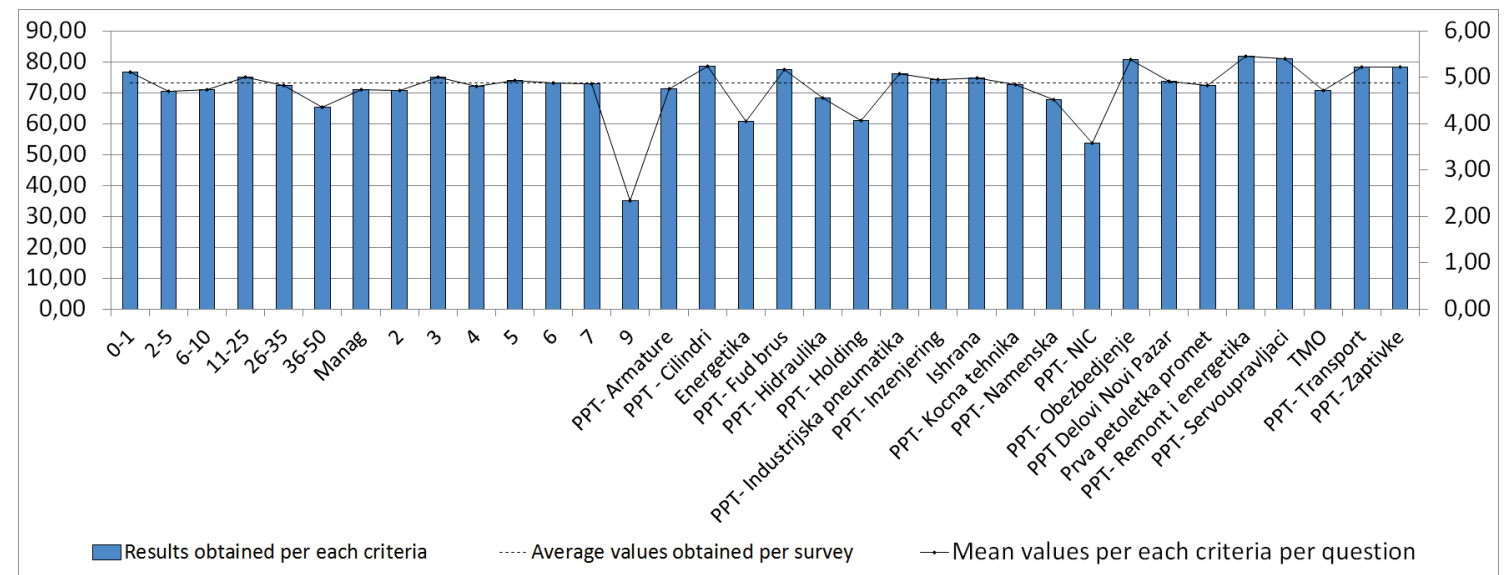

Figure 6 Points reached per each company, per LE, per YWE, mean value

All companies involved in this research have implemented QMS and made a great effort to survive in the newly created transition conditions. However, the long crisis and business based on contractual economy have left a deep impact on their organizational culture, especially with respect to the awareness of the need for being market-oriented, so the level of it is very low and those companies have not succeeded in implementing the principles of market orientation in their organizational structure and behaviour. Political influence and inadequate state assistance have particularly contributed to this state, which slowed down so needed changes.

The results obtained in this study show that organizational culture in the metal complex in Serbia is very strong, but it is still product and sales oriented, and the road to market orientation is still long. That road 
implies the total company reengineering, which should cover all processes in the company and all managerial levels, and it should be based on market-oriented organizational culture which will include all specificities of national cultures. New models for reengineering of the companies in transition should be provided, but also new educational systems for support in building new awareness about the need to be market oriented.

The identified level of market orientation should provide the starting point for definition of the new methodology, and the analysis of influential factors should help in defining the entities which should be particularly influenced and trained so that the proposed methodology could be successful and lead to the recovery of those companies and their involvement in the global market as soon as possible.

\section{References}

[1] George, J. M.; Jones, G. R. Understanding and managing Organizational Behaviour. Addison-Wesley Publisher, Reading, 1996.

[2] Gilgeous, V. Operations and the Management of Change, Pitman Publisher, London, 1997.

[3] Rashid, Z. A.; Sambasivan, M.; Rahman, A. The influence of organizational culture on attitudes toward organizational change. // Leadership \& Organization Development Journal. 25, 2(2004), pp. 161-179. DOI: 10.1108/01437730410521831

[4] Guangming, C.; Clarke, S.; Lehaney, B. A system view of organizational change and TQM. // The TQM magazine. 12, 3(2000), pp. 186-193. DOI: 10.1108/09544780010320241

[5] Gunasekaran, A. Enablers of total quality management implementation on manufacturing: a case study. // Total Quality Management. 40, (1999), pp. 987-996. DOI: 10.1080/0954412997172

[6] Youssef, M. A; Boyd, J.; Williams, E. The impact of total quality management on firms responsiveness: an empirical analysis. // Total Quality Management. 7, 1(1996), pp. 127-144. DOI: $10.1080 / 09544129650035098$

[7] Salegna, G.; Fazel, F. Obstacles to implementing quality. // Quality Progress. 33, 7(2000), pp. 53-57.

[8] Mosadghrad, A. M. The impact of organizational culture on successful implementation of total quality management. // The QM Magazine. 18, 6(2006), pp. 606-25.

[9] Deming, W. E. Out of the Crisis, Center for Advanced Engineering Study. Massachusetts Institute of Technology, Cambridge, 1986.

[10] Juran, J. Juran on Leadership for Quality. Free Press, New York, 1989.

[11] Entrekin, L. V.; Pearson, C. A. A comparison of values espoused by quality and other managers. // Asia Pacific Journal of Human Resources. 33, 3(1995), pp. 130-139. DOI: $10.1177 / 103841119603300311$

[12] Benson, T. TQM: a child takes a first few faltering steps. // Industry Week. 242, 7(1993), pp. 16-17.

[13] Gatchalian, M. People empowerment: the key to TQM success. // The TQM magazine. 9, 6(1997), pp. 429-433. DOI: 10.1108/09544789710187037

[14] Schonberger, R. Total quality management cuts a broad swathe - through manufacturing and beyond. // Organizational Dynamics. 21, 4(1992), pp. 16-27. DOl: 10.1016/0090-2616(92)90072-U

[15] Kujala, J.; Lillrank, P. Total quality management and a cultural phenomenon. // QMJ. 11, 4(2004), pp. 43-55.

[16] Rad, A. M. M. The impact of organizational culture on the successful implementation of total quality management. // The TQM Magazine. 18, 6(2006), pp. 606-625. DOI:

\subsection{8/09544780610707101}

[17] Pool, S. W. The learning organization: motivating employees by integrating TQM philosophy in a supportive organizational culture. // Leadership \& Organization Development Journal. 21, 8(2000), pp. 373-378. DOI: 10.1108/01437730010379276

[18] Grover, V.; Jeong, S. R.; Kettinger, W. J.; Teng, J. T. C. I. The implementation of business process reengineering. // Journal of Management Informational System. 12, 1(1995), pp. 10-144. http:/www.jstor.org/stable/40398155.

[19] Marchanad, D.; Stanford, M. Business process redesign: a framework for harmonizing people, information and technology, Business Process Change: Concepts, Methods and Technologies. Ideas Publishing, Harrisburg, 1995.

[20] Wells, M. G. Business process re-engineering implementations using internet technology. // Business Process Management Journal. 6, 2(2000) pp. 164-184. DOI: 10.1108/14637150010321303

[21] Slater, S. F. Market orientation at the beginning of new millennium. // Managing Service Quality. 11, 4(2001), pp. 230-232, DOI: 10.1108/EUM0000000005609

[22] Rodriguez, C.; Carillat, F.; Jaramillo, F. A meta-analysis of the relationship between market Orientation and Business Performance: Evidence from Five Continents. // International Journal of Research in Marketing. 21, (2000), pp.179-200. DOI: 10.1016/j.jjresmar.2003.07.001

[23] Pecić, Lj.; Klarin,M.; Trifunović, D.; Dašić, P. Marketingoriented organizational culture and implementation of total quality management - The case study of Prva petoletka. // Metalurgia International. 18, 6(2013), pp.121126.

[24] Pecić, Lj.; Kolarević, M. Marketing Oriented Organizational Culture as Prerequisite for TQM Implementation: the Case Study of Serbian Mechanical Industry. Proceedings from VIII International Conference Heavy Machinery/Zlatibor, , 2014, B27-35

[25] MARK-PLAN. Taboo, 5(2003), pp. 3.

\section{Authors' addresses}

mr Ljiljana Pecić, dipl. ing. maš.

College of Applied Professional Mechanical Studies Trstenik Radoja Krstića 19

37240 Trstenik, Serbia

E-mail: 1jiljana.pecic72@gmail.com

\section{dr Milivoj Klarin, full professor}

Mechanical Faculty Belgrade,

Faculty of Technical Science Zrenjanin, Serbia

E-mail: mklarin@open.telekom.rs 